\title{
Comparative Studies of the Physicochemical Properties and Heavy Metals adsorption Capacity of Chemical Activated Carbon from Palm Kernel, Coconut and Groundnut Shells
}

\author{
${ }^{* 1,2,3}$ BOADU, KO; ${ }^{3} \mathrm{JOEL}, \mathrm{OF} ;{ }^{2}$ ESSUMANG, DK; ${ }^{3}$ EVBUOMWAN, BO \\ ${ }^{I}$ World Bank Africa Centre of Excellence, Centre for Oil Fields Chemicals, Institute of Petroleum Studies, University of Port Harcourt, \\ Nigeria \\ ${ }^{2}$ Department of Chemistry, University of Cape Coast, Cape Coast, Ghana \\ ${ }^{3}$ Department of Chemical Engineering, University of Port Harcourt, Port Harcourt, Nigeria \\ *Corresponding Author Email: koboadu@ucc.edu.gh, boadu.kwasi@aceuniport.org
}

\begin{abstract}
Comparative studies of the physicochemical properties of chemical activated carbon from palm kernel (PKS), coconut (CNS) and groundnut (GNS) shells were investigated. The properties investigated were $\mathrm{pH}$, moisture content, specific gravity, BET surface area, pore volume, porosity, ash content and metal ions present. From the results obtained, the chemical activated carbon prepared from palm kernel, coconut and groundnut shells shows good physicochemical properties and adsorption capacity. However coconut shell with BET surface area $1177.520\left(\mathrm{~m}^{2} / \mathrm{g}\right)$, potassium content of $179.33 \mathrm{ppm}$ and $\mathrm{pH} 7.5$, having a better advantage to be used as organic fertilizer compare to groundnut shell with BET surface area $950.069\left(\mathrm{~m}^{2} / \mathrm{g}\right)$, potassium content of $140.00 \mathrm{ppm} \mathrm{\&} \mathrm{pH} 8.4$ and palm kernel shell with BET surface area $717.142\left(\mathrm{~m}^{2} / \mathrm{g}\right)$, potassium content of $128.00 \mathrm{ppm}$ and $\mathrm{pH} 8.7$ respectively in that order. Also, coconut shell with pore diameter of $2.840 \mathrm{e}+00$, specific gravity of $1.42 \&$ moisture content of $19.7 \%$ makes it a prefer option compare to groundnut shell with pore diameter of $2.920 \mathrm{e}+00$, specific gravity of 148 \& moisture content of $19.8 \%$ and palm kernel shell with pore diameter of $2.840 \mathrm{e}+00$, specific gravity of 1.61 and moisture content of $20.4 \%$ respectively.
\end{abstract}

DOI: https://dx.doi.org/10.4314/jasem.v22i11.19

Copyright: Copyright $\odot 2018$ Boadu et al. This is an open access article distributed under the Creative Commons Attribution License (CCL), which permits unrestricted use, distribution, and reproduction in any medium, provided the original work is properly cited.

Dates: Received: 12 November 2018; Revised: 26 November 2018; Accepted 30 November 2018

Keywords: Chemical activated carbons, physicochemical properties, BET surface area and heavy metals

Activated carbon is a special type of carbonaceous substance. It has highly crystalline form and extensively developed internal pore structure Tan and Hameed (2017). Due to activation, internal pore network is created which imparts certain surface chemistries (functional groups) inside each particle. Thus carbon gets its unique characteristics leading to high surface area, porosity and greater strength Hattab, et al., (2013). The absorptivity of the adsorbent depends on both the size of the molecule being adsorbed and the pore size of the adsorbent Kamal and Khan (2009). The organic material which has high carbon content is used as the raw material for the synthesis of activated carbon. There are many cheap, easily available materials such as palm kernel shell, coconut shell and groundnut shell which have been used extensively as the source for the synthesis of activated carbon Ani, et al., (2015). Oil Palm (Elaeis guineensis) is the most prominent species in the Elaeis genus which belongs to the family Palamae. It is cultivated in West Africa and in all tropical areas especially in Malaysia, Indonesia and Thailand. The oil extracted from the fruit pulp is used for edible purposes whilst the extracted oil from the kernel is mainly used for manufacturing of soap Abdullah, M,A Nazir, et al., (2011). Palm oil is one of the world's largest source of edible oil with 38.5 million tonnes or $25 \%$ of the world's total oil and fat production Evbuomwan, et al., (2013). . The waste products from oil palm processing consist of oil palm trunks, oil palm fronds, empty fruit bunches, and palm pressed fibres, palm kernel shells, less fibrous material such as palm kernel cake and liquid discharge palm mill effluent Singh, et al (2010) and Singhabhandhu and Tezuka (2010). Also, the coconut tree (Cocos nucifera) is a member of the family Arecaceae (palm family) and the only living species of the genus Cocos. The husks and leaves can be used as material to make a variety of products for furnishing and decorating. The coconut also has cultural and religious significance in certain societies, particularly in India, where it is used in Hindu rituals. IAW, et al, (2008). Furthermore, groundnut botanically belongs to Araches hypo Gaea Linn of leguminous family. Groundnut is a selfpollinated; annual and herbaceous legume crop. The shell constitute about $25-35 \%$ of the pod. The seed accounts for the remaining portion (65-75\%) Sada, et al., (2013). Within the world countries, Nigeria is 
among the foremost producers of groundnut, with an annual production rate of about 2.699 million metric tonnes in 2002 and 1.55 million tonnes in 2008 Sada, et al., (2013). It has the potential to produce high tonnes in future due to high demand from groundnuts products such as groundnut oil, spread, paste and concentrate. Over the years, palm kernel, coconut and groundnut shells are among the major solid waste especially in the developing countries of the world. Their potential as a very useful engineering materials has not been fully investigated and utilised. The utilization of these shells will reduce waste management cost, leads to clean environment as result of pollution reduction and the increase in financial base of the farmer when such waste are sold as raw materials. They are used in the abatement of hazardous contamination of the environment. Thus the aim of this research work is to do a comparative studies of the Physico-Chemical Properties and Heavy Metals adsorption capacity of Chemical Activated Carbon from Palm Kernel, Coconut and Groundnut Shells.

\section{MATERIALS AND METHODS}

Sample Collection and Preparation: The palm kernel, coconut and groundnut shells were collected from traditional palm oil, coconut and groundnut industries in Aluu and Choba respectively, Obio-Akpor local government area, Rivers State, Nigeria. The samples were washed repeatedly with tap water in order to remove all the dirt's, dusts and other contaminants. They were further washed with distilled water and sundried for 4 days. The dried samples were ground to obtain a powder forms. They were then sieved with a $500 \mu \mathrm{m}$ mesh and stored in air-tight containers for further analyses.

Chemical Activation and Carbonization: Activated Carbons were prepared from the palm kernel, coconut and groundnut shells using chemical activation method described by Evbuomwan, et al., (2013). 30g of the powdered samples each that is palm kernel, coconut and groundnut shells respectively were treated with $1 \mathrm{M}$ solution of $\mathrm{K}_{2} \mathrm{CO}_{3}$ and $\mathrm{NaHCO}_{3}$. They were then activated for 40 minutes at a carbonization temperature of $800^{\circ} \mathrm{C}$ using Carbolite Muffle Furnaces. The activated carbons produced were washed with $0.5 \mathrm{M}$ acetic acid solution, rinsed thoroughly with distilled water until the $\mathrm{pH}$ were within the range of 6-7. The samples were sun-dried and sieved with $500 \mu \mathrm{m}$ mesh. Portions of the activated carbons retained on the mesh were oven dried for 1 hour and stored in air-tight containers.

Determination of Physicochemical Properties of the Activated Carbons from Coconut, Groundnut and Palm Kernel Shells: pH Measurement: $1 \mathrm{~g}$ of the samples each (palm kernel, coconut and groundnut shells) were weighed and dissolved in $3 \mathrm{ml}$ of deionized water.. The various mixtures were heated and stirred for 3 minutes to ensure proper dilution of the samples. The solutions were filtered out and their $\mathrm{pH}$ were determined using a digital $\mathrm{pH}$ meter Madu and Lajide (2013).

Determination of Moisture Content: The hydroscopic moisture content were determined using the ASTM D 280-33. Clean empty nickel porcelain were oven dried at $110^{\circ} \mathrm{C}$, cooled in a desiccator and then weighed. $1 \mathrm{~g}$ of the samples each (palm kernel, coconut and groundnut shells) were measured into the porcelain separately and the weights recorded. The porcelain and their contents were then oven dried at $110^{\circ} \mathrm{C}$ to a constant weight for 3 hours. The percentage moisture content was calculated using the formula Madu, P. C.1 and Lajide, L.; (2013).

$$
\mathrm{X}_{0=\frac{\mathrm{W}_{1}-\mathrm{W}_{2}}{\mathrm{~W}_{1}} \times 100 \%}
$$

Where: $\mathrm{X}_{0}=$ Moisture content on wet basis; $\mathrm{W}_{1}=$ Initial weight of sample, $\mathrm{g} ; \mathrm{W}_{2}=$ Final weight of sample after drying $(\mathrm{g})$

Ash Content Determination: Ash content determination was done according to the ASTM D 2866-94 method Verla, et al., (2012). Dry activated carbon samples each (palm kernel, coconut and groundnut shells) were placed into a porcelain crucibles and transferred into a preheated muffle furnace set at a temperature of $1000{ }^{\circ} \mathrm{C}$. The furnace was left on for one hour after which the crucible and their contents were transferred to desiccator and allowed to cool. The crucible and their contents were reweighed and the weight lost were recorded as the ash content of the activated carbon samples $\left(\mathrm{W}_{\text {ash }}\right)$. Then, the $\%$ ash content (dry basis) were calculated from the equation below

$$
\operatorname{Ash}(\%)=\frac{W_{C \& S}-\mathrm{w}_{\mathrm{c}}}{\mathrm{w}_{0}} \times 100 \%
$$

Where: $\mathrm{W}_{\mathrm{C}}=$ Weight of crucible; $\mathrm{W}_{\mathrm{c} \& \mathrm{~S}}=$ Weight crucible and sample after ashing (grams); $\mathrm{W}_{0}=$ Dry weight of carbon sample before ashing.

Pore Volume Measurement: $1 \mathrm{~g}$ each of the samples (palm kernel, coconut and groundnut shells) were collected and transferred completely into a $10 \mathrm{ml}$ measuring cylinders in order to get the total volume of the samples. The samples were then poured each into a beaker containing $20 \mathrm{ml}$ of de-ionized water and boiled for 5 minutes. The content in the beakers were then filtered, superficially dried, and weighed. The pore volume of the samples were determined by 
dividing the increase in weight of the sample by the density of water Madu and Lajide (2013).

Bulk Density and Porosity Determination: The bulk density and porosity were determined by the method of Verla, et al., (2012). A cylinder and an aluminium plate were each weighed. Samples of activated carbons (palm kernel, coconut and groundnut shells) were placed into the cylinders each, reweighed and transferred into the aluminium plate and the oven dried to a constant weight at a temperature of $105{ }^{\circ} \mathrm{C}$ for 60 minutes. The weights of the dried samples were recorded after drying. A cleaned, dried well-corked density bottles were weighed. A small quantity of activated carbon of each samples (palm kernel, coconut and groundnut shells) were taken and ground to powder; sieved using $110 \mu \mathrm{m}$ mesh size, and gradually put into the density bottles each with little amount of water added and weighed. The volumes of the void $\left(\mathrm{V}_{\mathrm{v}}\right)$ were obtained by first determining the total volume of the cylinders each $\left(V_{t}=\pi r^{2} h\right)$ used for the experiments and also determining the volumes of the activated carbons used.

$$
V_{s=\frac{M_{S}}{G_{S} P_{w}}}
$$

Where: $\mathrm{r}=$ radius of cylinder $\mathrm{h}=$ height of cylinder, $\mathrm{M}_{\mathrm{s}}=$ mass of cylinder, $\mathrm{G}_{\mathrm{s}}=$ Specific gravity; $\mathrm{P}_{\mathrm{w}}=$ density of water; The volume of void $\left(\mathrm{V}_{\mathrm{v}}\right)$ was obtained as: $V_{v}=V_{t}-V_{s}$; The bulk density and porosity were calculated as;

$$
\begin{gathered}
\text { Bulk density }(B . d)=\frac{\text { mass of carbon sample }}{\text { volume }} \\
\text { porosity }\left(\eta^{\prime}\right)=\frac{\text { volume of void }}{\text { Total volume }}
\end{gathered}
$$

Surface Area Determination: The specific surface areas of the activated carbon samples (palm kernel, coconut and groundnut shells) were determined using BET instrument applied by Particle Analytical (Micromeritics Gemini 2375 and Gemini V) determines the specific surface area $\left(\mathrm{m}^{2} / \mathrm{g}\right)$ of samples. The samples are dried with nitrogen purging or in a vacuum applying elevated temperatures. Unless otherwise instructed we use P/P0 of $0,1,0,2$ and 0,3 as standard measurement points. The volume of gas adsorbed to the surface of the particles were measured at the boiling point of nitrogen $\left(-196^{\circ} \mathrm{C}\right)$. The amount of adsorbed gas were correlated to the total surface area of the particles including pores in the surface. The calculation were based on the BET theory. Traditionally nitrogen were used as adsorbate gas. Gas adsorption also enables the determination of size and volume distribution of micropores $(0.35-2.0 \mathrm{~nm})$.
The surface area determined by BET was thus normally larger than the surface area determined by air permeability. The method used complies with $\mathrm{Ph}$. Eu.2.9.26 Method II.

Determination of Heavy Metals Contained in the Samples: The heavy metals present in the activated carbon samples (palm kernel, coconut and groundnut shells) were determined using a Perkin Elmer Atomic Absorption Spectrophotometer. Bentum, et al., (2011) and (Evbuomwan, et al., (2013).

Statistical treatment of Data: The data generated from these research work were analysed using both Excel version 2013 and IBM SPSS version 23.

\section{RESULTS AND DISCUSSION}

The results of the of the research carried out on the comparative studies of the physicochemical properties and metals present in chemically activated carbon from palm kernel, coconut and groundnut shells have been carefully detailed in the tables 1-4 and figure 1 . Tables 1-3 shows the physicochemical parameters, concentration of metals present and one-way ANOVA in SPSS Statistics. Figure.1 shows the graph of the concentration of heavy metals obtained.

$p H$ : Effect of $\mathrm{pH}$ on the adsorption process $\mathrm{pH}$ is one of the most important environmental factors influencing not only site dissociation, but also the solution chemistry of heavy metal: hydrolysis, complexation by organic and/or inorganic ligands, redox reactions, and precipitation are strongly influenced by $\mathrm{pH}$ and on the other hand, it strongly influences the speciation and adsorption availability of heavy metals Sekar, et al., (2004). From table. 1, the $\mathrm{pH}$ of the samples were found to be 7.5, 8.4 and 8.7 for coconut, groundnut and palm kernel shells respectively. The adsorption of the adsorbent (chemically activated carbon) increased with increasing $\mathrm{pH}$. Similar result was found by Liu, J. et $a l .$, (2007). The value of $\mathrm{pH}$ obtained in this analyses were ideal for adsorption purposes as maximum adsorption of metals by most activated carbon occur at this pH Nwabanne and Igbokwe (2012). Carbons of $\mathrm{pH}$ 6-9 are useful for most applications Okiemmen, et al., (2007).

Moisture (\%): Moisture is the presence of a liquid, especially water, often in trace amounts. Moisture has different effects on different products, influencing the final quality of the product under study. From table 1, moisture content chemically activated carbons were $19.7 \%, 19.8 \%$ and $20.4 \%$ respectively for coconut, groundnut and palm kernel shells. Moisture content tended to be usually the same for coconut and 
groundnut shells whiles slightly higher for palm kernel shell showing that these carbons were properly prepared and handheld. It should be noted that when exposed to air the AC are capable of adsorbing moisture from atmosphere. This normally could lead to high moisture content Verla, et al., (2012) and Evbuomwan, et al., (2013).

Ash content (\%): The ash content is a measure of the total amount of minerals present within a material, whereas the mineral content is a measure of the amount of specific inorganic components present within a material, such as $\mathrm{Ca}, \mathrm{Na}, \mathrm{K}$ and $\mathrm{Cl}$. From the results obtained in table 1 , the ash content of the samples are $11.7 \%, 12.3 \%$ and $14.2 \%$ for groundnut, coconut and palm kernel shells respectively. The presence of appreciable amount of ash contents in all the samples indicates that they can be use a potential sources of organic fertilizer. However higher levels of ash contents reduces the overall activity of activated carbon and it reduces the efficiency of reactivation. Also, the presence of ash has been shown to inhibit surface development Valix, et al., (2004).

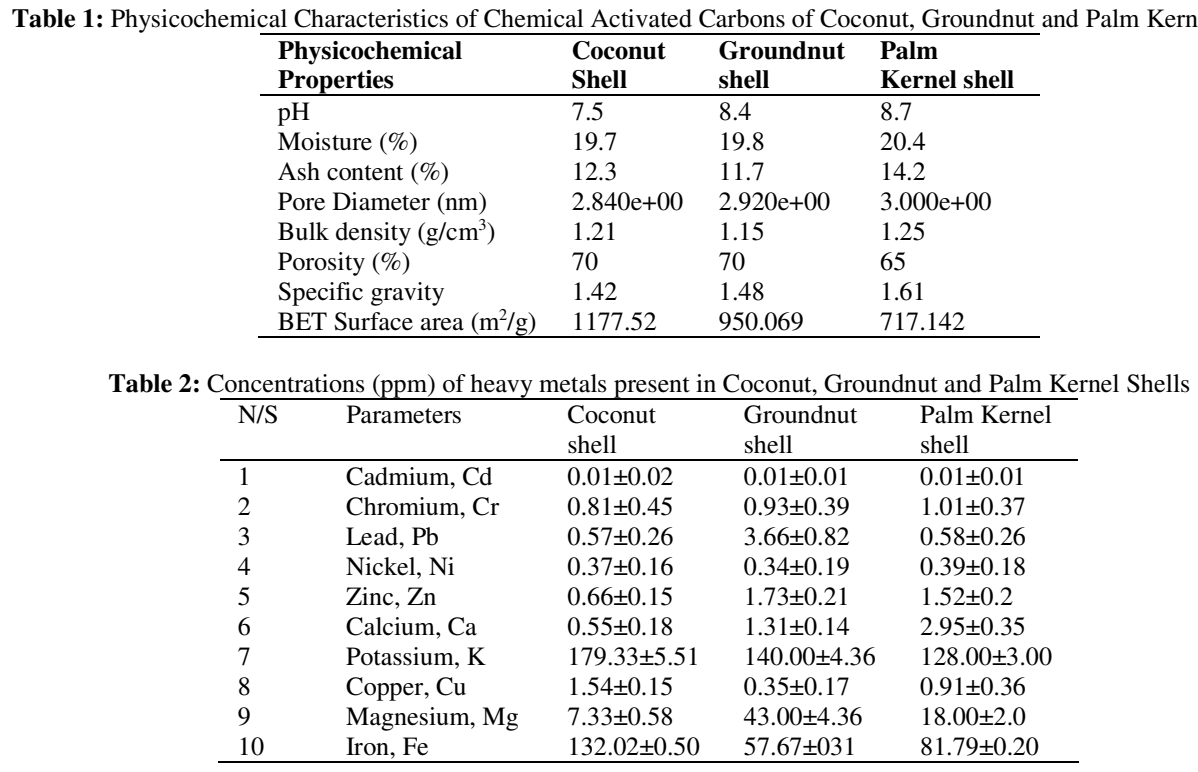

Pore Diameter $(\mathrm{nm})$ : From the results obtained in table 1 , the pore diameter were $2.840 \mathrm{e}+00 \mathrm{~nm}, 2.920 \mathrm{e}+00$ $\mathrm{nm}$ and $3.000 \mathrm{e}+00$ for coconut, groundnut and palm kernel shells respectively. If the pore diameters are smaller than $2 \mathrm{~nm}$, these are called micro- pores. If their sizes are between 2 and $50 \mathrm{~nm}$, these are called meso-pores. Also, the material is named macro-porous if their sizes are larger than $50 \mathrm{~nm}$. The adsorption capacity of the macro- porous materials is at a negligible level compared to that for the micro- and meso-porous adsorbents Kirali and Lacin, (2006) and Salem, et al., (2014). From literature values it was found out the value obtained falls within the acceptable range for meso-porous adsorbents.

Bulk density $\left(\mathrm{g} / \mathrm{cm}^{3}\right)$ : Bulk density is the weight of soil or powder substance in a given volume. Soils or powder substance with a bulk density higher than 1.6 $\mathrm{g} / \mathrm{cm}^{3}$ tend to restrict root growth. It increases with compaction and tends to increase with depth. The bulk density $\left(\mathrm{g} / \mathrm{cm}^{3}\right)$ obtained were $1.21\left(\mathrm{~g} / \mathrm{cm}^{3}\right), 1.15$ $\left(\mathrm{g} / \mathrm{cm}^{3}\right)$ and 1.25 respectively for coconut, groundnut and palm kernel shells. These results are slightly higher than to those found in literature (Nwabanne and Igbokwe, 2012). However, these results shows that the samples studied were within the recommended values for bulk density making it ideal for adsorbents.

Porosity (\%): Pore size distribution has been used to describe the internal structures and adsorption capacities of activated carbons (Dalye and Tandon, 1996).The pore characteristics of the activated charcoal are a determining factor in its rate and ability to adsorb toxins (Ilomuanya, et al., 2017). From table 1 , the porosity of the samples were $70 \%, 70 \%$ and $65 \%$ for coconut, groundnut and palm kernel shells respectively. The high micro porosity in the activated carbon samples suggests potential applications in gasphase adsorption for air pollution control Patrick, (1995) and Guo and Lua (2000).

Specific gravity: Specific gravity is the ratio of the mass of volume of substance to the mass of the same volume of water and depends on two temperatures, at 
which the mass of the sample and the water are measured. Specific gravity is influenced by the chemical composition of the oil (Hamawand et al., 2013). The specific gravity values obtained from table 1 are $1.42,1.48$ and 1.61 for coconut, groundnut and palm kernel shells respectively. The values obtained are within the specific gravity range of $0.8-2.1$ for activated carbons found in material safety data sheets. (CAS Number: 7440-44-0; EC Number: 231-153-3).

BET Surface area $\left(\mathrm{m}^{2} / \mathrm{g}\right)$ : Specific surface area is a scale-dependent property, with no single true value of specific surface area definable, and thus quantities of specific surface area determined through BET theory may depend on the adsorbate molecule utilized and its adsorption cross section (Hanaor, et al., 2014). The BET surface area values obtained are $1177.520\left(\mathrm{~m}^{2} / \mathrm{g}\right)$, $950.07\left(\mathrm{~m}^{2} / \mathrm{g}\right)$ and $717.142\left(\mathrm{~m}^{2} / \mathrm{g}\right)$ respectively for coconut, groundnut and palm kernel shells. The high BET surface area values obtained, indicates the presence of many adsorption sites and thus showing desirable characteristics for potential use as pollutant adsorbent in used lubricating oils. Liew et al., (2018).

Table 3: One-way Anova in SPSS Statistics of the chemical activated carbons from coconut, groundnut and palm kernel shells

\begin{tabular}{|c|c|c|c|c|c|c|}
\hline & & Sum of Squares & df & Mean Square & $F$ & Sig. \\
\hline Copper & $\begin{array}{l}\text { Between Groups } \\
\text { Within Groups } \\
\text { Total }\end{array}$ & \begin{tabular}{|l|}
2.115 \\
362 \\
2.476 \\
\end{tabular} & $\begin{array}{l}2 \\
6 \\
8 \\
\end{array}$ & $\begin{array}{l}1.057 \\
.060\end{array}$ & 17.550 & .003 \\
\hline Iron & $\begin{array}{l}\text { Between Groups } \\
\text { Within Groups } \\
\text { Total }\end{array}$ & $\begin{array}{l}8633.889 \\
774 \\
8634.663 \\
\end{array}$ & $\begin{array}{l}2 \\
6 \\
8 \\
\end{array}$ & $\begin{array}{l}4316.944 \\
129\end{array}$ & $\begin{array}{l}33464.68 \\
5\end{array}$ & .000 \\
\hline Zine & $\begin{array}{l}\text { Between Groups } \\
\text { Within Groups } \\
\text { Total }\end{array}$ & $\begin{array}{l}1.929 \\
210 \\
2.139 \\
\end{array}$ & $\begin{array}{l}2 \\
6 \\
8\end{array}$ & $\begin{array}{l}.964 \\
.035\end{array}$ & 27.551 & .001 \\
\hline Cadmium & $\begin{array}{l}\text { Between Groups } \\
\text { Within Groups } \\
\text { Total }\end{array}$ & $\begin{array}{l}.000 \\
.001 \\
.001 \\
\end{array}$ & $\begin{array}{l}2 \\
6 \\
8 \\
\end{array}$ & $\begin{array}{l}.000 \\
.000\end{array}$ & 176 & .842 \\
\hline Lead & $\begin{array}{l}\text { Between Groups } \\
\text { Within Groups } \\
\text { Total }\end{array}$ & \begin{tabular}{|l|}
19.014 \\
1.618 \\
20.632 \\
\end{tabular} & $\begin{array}{l}2 \\
6 \\
8\end{array}$ & $\begin{array}{l}9.507 \\
270\end{array}$ & 35.256 & .000 \\
\hline Chromium & $\begin{array}{l}\text { Between Groups } \\
\text { Within Groups } \\
\text { Total }\end{array}$ & \begin{tabular}{|l|}
.059 \\
977 \\
1.036 \\
\end{tabular} & $\begin{array}{l}2 \\
6 \\
8\end{array}$ & $\begin{array}{l}.029 \\
.163\end{array}$ & .181 & .839 \\
\hline Magnessium & $\begin{array}{l}\text { Between Groups } \\
\text { Within Groups } \\
\text { Total }\end{array}$ & \begin{tabular}{|l|}
2010.889 \\
46.667 \\
2057.556 \\
\end{tabular} & $\begin{array}{l}2 \\
6 \\
8 \\
\end{array}$ & $\begin{array}{l}1005.444 \\
7.778\end{array}$ & 129.271 & .000 \\
\hline Nickel & $\begin{array}{l}\text { Between Groups } \\
\text { Within Groups } \\
\text { Tota1 }\end{array}$ & \begin{tabular}{|l|}
.003 \\
.190 \\
.193 \\
\end{tabular} & $\begin{array}{l}2 \\
6 \\
8 \\
\end{array}$ & $\begin{array}{l}.001 \\
.032\end{array}$ & .047 & .955 \\
\hline Calcium & $\begin{array}{l}\text { Between Groups } \\
\text { Within Groups } \\
\text { Tota1 }\end{array}$ & \begin{tabular}{|l|}
9.075 \\
346 \\
9.421 \\
\end{tabular} & $\begin{array}{l}2 \\
6 \\
8 \\
\end{array}$ & $\begin{array}{l}4.538 \\
.058\end{array}$ & 78.702 & .000 \\
\hline Potas sium & $\begin{array}{l}\text { Between Groups } \\
\text { Within Groups } \\
\text { Tota1 }\end{array}$ & $\begin{array}{l}4326.222 \\
116.667 \\
4442.889 \\
\end{array}$ & $\begin{array}{l}2 \\
6 \\
8\end{array}$ & $\begin{array}{l}2163.111 \\
19.444\end{array}$ & 111.246 & .000 \\
\hline
\end{tabular}

*. The mean difference is significant at the 0.05 level.

Heavy Metals ( ppm): Heavy metals are naturally found on the earth's crust through anthropogenic activities. They cannot be degraded or destroyed by living organisms. To some extent they enter our living organisms via food, drinking water, air, adsorption, absorption etc. As trace elements, some heavy metals (e.g. Copper, selenium, zinc) are essential to maintain the metabolism of the human body. However, at higher concentrations they can lead to poisoning Evbuomwan et al., (2013). Heavy metal poisoning could result from drinking-water contaminated with lead (e.g. lead pipes), high ambient air concentrations near emission sources, or intake via the food chain (Kpan et al., 2014). Results from the heavy metal analyses of the activated carbon samples from Table 2 above, reveals that the toxic metals such as: Cadmium $(\mathrm{Cd})$ and Nickel (Ni) were below the detected limits, whereas, Chromium, Lead, Copper, Zinc, Calcium,
Potassium, Copper, Iron and Magnesium were above the detected limits. Potassium is oxidized easily, thus reducing the available oxidizing agents (Udoetok, 2012). The high concentration of Potassium in this sample and the presence of other metals like Zinc, Iron, Calcium and Magnesium makes it suitable for use in conditions reactions where reduction is paramount (Udoetok, 2012). Also since the toxic metals detected and not detected in the activated carbons from coconut, groundnut and palm kernel shells can be used in removing these toxic metals from waste water and used lubricating oil. From Fig.1 above: It can be observed that the concentration of Potassium in the samples are higher than other metals in the samples, with the concentration of Potassium in oil coconut higher than that in the groundnut and palm kernel shells. The high concentration of Potassium in the activated carbon samples form coconut, groundnut 
and palm kernel shells justifies its usage as organic fertilizer since Potassium is needed by plants in large quantities for growth and support (Udoetok, 2012).

One-way ANOVA in SPSS Statistics of the activated carbons from coconut, groundnut and palm kernel shells: As shown in table 3,there was a statistically significant difference between groups as determined by one-way ANOVA for the various metals are Copper $(F(2,6)=17.550, p=.003)$, Iron $(F(2,6)=33464.685$ $, p=.000)$,Zinc $(F(2,6)=27.551, p=.001)$, Lead $(F(2,6)=35.256, p=.000)$, Magnesium $(F(2,6)=$ $129.271, p=.000)$, Calcium $(F(2,6)=78.702, p=$ $.000)$ and Potassium $(F(2,6)=111.246, p=.000)$.

Conclusions: A comparative studies of the physicochemical properties and heavy metals adsorption capacity of chemical activated carbon from palm kernel, coconut and groundnut shells were carried out. The experimental analyses investigated shows that the activated carbons prepared from coconut, groundnut and palm kernel shells have good physicochemical properties for adsorption. However, it could reasonably be concluded that coconut shell with high BET surface area and potassium content have a better advantage to be used compare to groundnut shell and palm kernel shell. Also, coconut shell with good pore diameter would be more suitable than groundnut shell and palm kernel shell respectively.

Acknowledgements: Authors acknowledge the research grant provided by University of Cape Coast, Ghana and World Bank Africa Centre of Excellence, Centre for Oil Fields Chemicals, Institute of Petroleum Studies, University of Port Harcourt, Nigeria under the $\mathrm{PhD}$. research grant.

\section{REFERENCES}

Abdullah, MA; Nazir, MS; Wahjoedi, BA (2011). Development of value-added Biomaterials from Oil Palm Agro-wastes. 2nd International Conference on Biotechnology and Food Science IPCBEE vol.7I ACSIT Press, Singapore

Activated charcoal powder; CAS Number: 7440-44-0; EC Number: 231-153-3

Ani1, IJ; Okafor1, J.O; Olutoye, M A; Akpan, U G (2015). Effects of Process Variables and a Comparative Study of Methods for Transfer Oil Production from Spent Engine Oil, British Journal of Applied Science \& Technology 9(1): 65-76,
ASTM D 280-33 Standard Test Methods for the hydroscopic moisture content. ASTM, West Conshohocken, PA.

ASTM D 2866-94, Standard Test Methods for the ash content, ASTM, West Conshohocken, PA.

Bentum, JK; Anang, MA; Boadu, KO; KorantengAddo, EJ; (2011). Assessment of heavy metals pollution of sediments from Fosu lagoon in Ghana, Bulletin of the Chemical Society of Ethiopia, 25(2), 191-196.

Dalye, MA; Tandon, D (1996). Elucidating the porous structure of activated carbon fibers using direct and indirect methods. ; 34(10):1191-1200

Evbuomwan, BO; Agbede, AM.; Atuka, MM (2013). A Comparative Study of the Physico-Chemical Properties of Activated Carbon from Oil Palm Waste (Kernel Shell and Fibre), Inter. J. Sci. Engineer. Investigate. 2 (19) 75-79

Guo and Lua AC (2000). Effect of heating temperature on the properties of chars and activated carbons prepared from oil palm stones," J. Thermal Anal. Calorimetry. 60 (2) 417-425.

Hamawand, I; Yusaf, T; Rafat, S (2013). Recycling of Waste Engine Oils Using a New Washing Agent, 1023-1049.

Hanaor, DAH; Ghadiri, M; Chrzanowski, W; Gan, Y (2014). "Scalable Surface Area Characterization by Electrokinetic Analysis of Complex Anion Adsorption" (PDF). Langmuir. 30 (50):1514315152

Hattab, A; Bagane, M; Chlendi, M (2013). Characterisation of tataouine's raw and activated clay. Journal of Chemical Engineering Process Technology; 4(4):1-5.

IAW, Tan; AL, Ahmad; BH, Hameed (2008). Preparation of activated carbon from coconut husk: Optimization study on removal of 2, 4, 6trichlorophenol using response surface methodology, Journal of Hazardous Materials 153, pp. 709-717

Ilomuanya, M; Nashiru, B; Ifudu, N; Igwilo, C (2017). Effect of pore size and morphology of activated charcoal prepared from midribs of Elaeis guineensis on adsorption of poisons using metronidazole and Escherichia coli $\mathrm{O} 157: \mathrm{H} 7$ as a case study. Journal of Microscopy and Ultrastructure, 5(1), 32 . 
J, Sharma; R Chhabra, H; Yan, Y Liu (2007). Chemical Communications, .0, 477-479. pubs.rsc.org

Kamal, A; Khan, F (2009). Effect of extraction and adsorption on re-refining of used lubricating oil. Journal of Oil Gas Science and Technology; 64(2):191-197.

Kirali, EG and Laçin O, Statistical modelling of acid activation on cotton oil bleaching by Turkish bentonite, Journal of Food Engineering, 75, 137141(2006).

Kpan, JD A; Boadu, KO; Anukwah, G; (2014). Heavy Metal Pollution in Soil and Water in Some Selected Towns in Dunkwa-on-Offin District in the Central Region of Ghana as a Result of Small Scale Gold Mining. Journal of Agricultural Chemistry and Environment, 3pp.40-47.

Liew, RK; Nam, WL; Chong, MY; Phang, XY; Su, M H; Yek, PNY; Lam, SS; (2018). Oil palm waste: An abundant and promising feedstock for microwave pyrolysis conversion into good quality biochar with potential multi-applications. Process Safety and Environmental Protection, 115, pp.5769. doi:10.1016/j.psep.2017.10.005

Madu, PC; Lajide, L (2013). Physicochemical characteristics of activated charcoal derived from melon seed husk. Journal of Chemical and Pharmaceutical Research, 2013, 5(5):94-98.

Nwabanne, JT; Igbokwe, P K (2012). Comparative Study of Lead (II) Removal from Aqueous Solution Using Different Adsorbents, International Journal of Engineering Research and Applications. Vol. 2, Issue 4, July-August 2012, pp.1830-1838.

Okiemmen, F; Okiemen, C; Wuana, A. (2007). Preparation and characterization of activated carbon from rice husk. Journal of Chemical Society of Nigeria, 32, 126-136

Patrick, JW (1995). Porosity in Carbon: Characterization and Application, 1st edition. Edward Arnold Publishers, London, 3-252.
Sada, BH; Amartey, YD; Bako, S (2013). "An Investigation into the use of Groundnut Shell as Fine Aggregate Replacement", Nig. J. Technol. 32, (1) $54-60$.

Shiva, Salem; Amin, Salem; Aylin,Agha Babaei (2015). Application of Iranian Nano-porous Cabentonite for recovery of Waste Lubricant Oil by Distillation and Adsorption Techniques, Journal of Industrial and Engineering Chemistry (23), pp.154162 ,

Sekar, M., Sakthi, V., \& Rengaraj, S. (2004). Kinetics and equilibrium adsorption study of lead (II) onto activated carbon prepared from coconut shell. Journal of Colloid and Interface Science, 279(2), 307-313. doi:10.1016/j.jcis.2004.06.042

Singh, RP; M. Hakimi Ibrahim; Esa Norizan, (2010). Composting of waste from palm oil mill: A Sustainable waste management practice. Review in Environmental Science and Biotechnology, DOI: 10.1007/s11157-010-9199-2

Singhabhandhu, A; Tezuka, T (2010).The waste-toenergy framework for integrated multi-waste utilization: waste cooking oil, waste lubricating oil, and waste plastics. Energy; 35:2544e5

Tan, KL; Hameed, BH (2017). Insight into the adsorption kinetics models for the removal of contaminants from aqueous solutions, Journal of the Taiwan Institute of Chemical Engineers, (74), pp. $25-48$

Udoetok, IA (2012). Characterization of ash made from oil palm empty fruit bunches (oefb). International Journal of Environmental Sciences Volume 3 No.1. pp 518-524.

Valix, M; Cheung, WH; McKay, G; (2004). Preparation of activated carbon using low temperature carbonization and physical activation of high ash raw bagasse for acid dye adsorption, Chemosphere, 56, 493-51.

Verla, AW; Horsfall, M (Jnr). Verla, E.N. Spiff1, A.I. Ekpete, O.A. (2012): Preparation and Characterization of Activated Carbon from Fluted Pumpkin (Telfairia Occidentalis Hook. F) Seed Shell. Asian J. Nat. Appl. Sci. 39-50. 